\title{
The Impact of Non-Performing Loans, Return on Assets, Return on Equity, and Loan to Deposit Ratios on Minimum Capital Adequacy Requirement Based on Commercial Banks for Business Activities (BUKU) I 2015-2020
}

\author{
Rano Rahadian and Dudi Permana
}

\section{ABSTRACT}

\begin{abstract}
The purpose of this research is to gain an understanding of The Impact of NonPerforming Loans, Return on Assets, Return on Equity, and Loan to Deposit Ratios on Minimum Capital Adequacy Requirement Based on Commercial Banks for Business Activities (BUKU) I 2015-2020. The data of this research is obtained from financial reports published by each bank in 2015 to 2020 period. This research uses panel data processed using EViews software version 9.0. The results show that NPL negatively and insignificantly affects CAR. ROA gives positive and insignificant impacts toward CAR, while ROE causes negative and insignificant effects on CAR. In addition, there is positive and significant impacts on CAR caused by LDR.
\end{abstract}

Keywords: Commercial Banks for Business Activities (BUKU) I, Loan to Deposit Ratio (LDR), Minimum Capital Adequacy Requirement (CAR), Non-Performing Loan (NPL), Return on Asset (ROA), Return on Equity (ROE).

\author{
Submitted : September 01, 2021 \\ Published : November 14, 2021 \\ ISSN: $2507-1076$ \\ DOI: $10.24018 /$ ejbmr.2021.6.6.1084

\section{Rano Rahadian*} \\ University of Mercu Buana, Jakarta, Indonesia. \\ (e-mail: ranorahadian@gmail.com) \\ Dudi Permana, \\ Ph. D, University of Mercu Buana, Jakarta, \\ Indonesia. \\ (e-mail: dudi.permana ${ }^{\circledR}$ mercubuana.ac.id) \\ *Corresponding Author
}

\section{INTRODUCTION}

Bank capital is capital invested by the owner in the context of creating a business entity with the goal of providing funds for bank business activities while fulfilling the monetary authority's regulations. Capital is crucial to the banking business since it can help reduce the risks that may occur in the banking industry. Capital adequacy ratios are considered as a measure of the bank's ability to protect itself against unforeseen losses, while also supporting the future expansion and enhancing public confidence in the status of the bank and the scare of capital which significantly affects the bank's ability to run a business.

In 1988, The Bank for International Settlement (BIS) obtained a mutual agreement on bank capital provisions by establishing the capital adequacy ratio (CAR), which is the minimal ratio between risk capital and risky assets and formed a mutual agreement on the determination of bank capital. Banks all across the globe must follow CAR laws in order to compete fairly in global financial markets. The BIS sets the minimum capital-to-risky-assets ratio at $8 \%$.

BIS policies were initially non-binding, but they were eventually adopted by nearly all central banks across the world. Bank Indonesia implements this regulation by Bank Indonesia Regulation No. 3/21/PBI/2001, which controls the minimum capital adequacy requirement for commercial banks to become CAR (Minimum Capital Adequacy

Requirement) of up to $8 \%$. This regulation was revised by Financial Services Administration Regulation No.11/POJK.03/2016 on the Minimum Capital Adequacy
Requirement for Commercial Banks, which would progressively adjust the conditions of the Indonesian and international banking industries.

Stable and big profits generated by the bank's ability indicate that the bank is in healthy condition. If the bank can earn consistent and big profits, its capital will expand, which will benefit the company's performance and allow it to reduce risk and be ready to tackle challenges. For three years in a row, the performance of CAR in BUKU I in Indonesia has improved. Several previous studies discovered that the ability of the company to produce profitability through the performance of Return on Assets and Return on Equity has a substantial influence on the Capital Adequacy Ratio (Irdawati et al., 2018), (Fathiyah Andini \& Irni Yunita, 2015). However, other previous research found that the company's profitability has no major impact on the development of the Capital Adequacy Ratio (Prasetya Adi Pratama, 2013).

The growth in non-performing loans will also lead banks to encounter difficulties, and banks must maintain strong capital reserves in order to overcome problem loans, thus banks must maintain more capital in order to overcome problem loans. Previous research has discovered that NPL has a substantial influence on CAR performance. However, some prior researches have indicated that NPL has no effect on the growth of the Capital Adequacy Ratio (Yuliani\& Edy, 2015).

According to Kasmir (2014), not only is liquidity connected to a company's overall financial position, but also to its competence in turning specific liquid assets into cash. If the bank manages its liquidity properly, the company's capital 
will grow in order to meet its responsibilities. Several prior research revealed that the Loan to Deposit Ratio has a substantial impact on CAR performance. Nonetheless, prior research revealed that LDR has no substantial influence on the growth of the Capital Adequacy Ratio (Purnama Sari, 2016).

According to Fig. 1 below, it is known that Minimum Capital Adequacy Requirement (CAR) had increased in BUKU I in Indonesia in 2015-2.

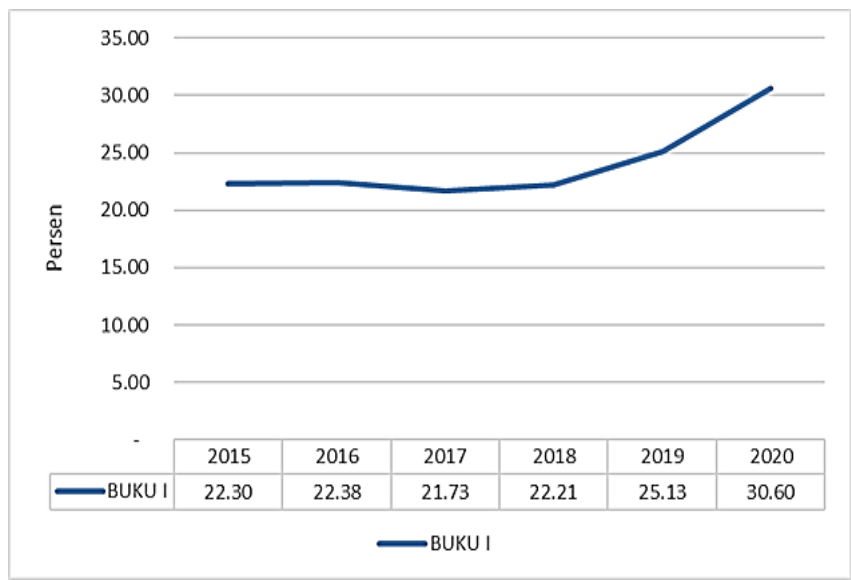

Fig 1. Performance of CAR BUKU I 2015-2020. Source: processed from the Indonesian Banking System Table 1.26-1.29 (2020).

Based on the description and research gap above, the researchers raise the title "The Effect of Non-Performing Loans, Return on Assets, Return on Equity and Loan to Deposit Ratios on Bank Minimum Capital Adequacy Requirement based on Commercial Banks Business Activities (BUKU) I 2015-2020".

\section{RESEARCH METHODOLOGY}

\section{A. Type of Research}

Quantitative research is used in this study. This method converts data into numbers in order to examine the results. This study utilises a causality study design. "Causal research is study whose major aim is to prove a cause-and-effect connection or a relation that affects and is impacted by the factors investigated,", stated Istijanto (2005). As a result, the author will attempt to identify the variables that influence how other variables change. The following is a systematic explanation of the relation between NPL, ROA, ROE, and LDR and KPPM or CAR:

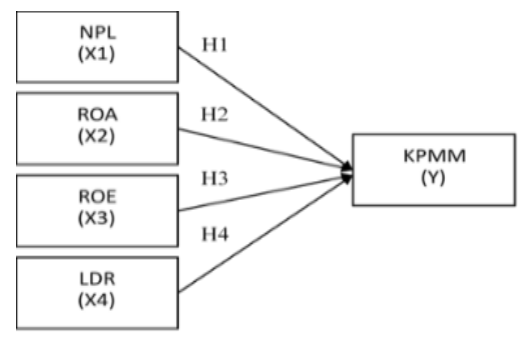

Fig 2. Relation between NPL, ROA, ROE, and LDR and KPPM or CAR.

\section{B. Sample and Population}

The population of this research are banking businesses that are categorised based on commercial bank business activities.
This research uses the purposive sampling method, which is as follows:

a. Classified based on commercial bank business activities, namely BUKU I in the 2015-2020 period.

b. The financial Reports published by the bank completely from the 2015-2019 period.

\section{Data Analysis}

This study uses multiple linear regression analysis to determine the influence of numerous independent variables on the dependent variables in terms of professional development.

\section{Hypothesis Development}

1) The Effect of Non-Performing Loans on the Minimum Capital Adequacy Requirement (CAR)

According to Riyadi (2006), NPL is the number of nonperforming loans in comparison to the total loans granted. If the NPL rate rises, the cost of provision to cover losses may exceed the interest income from loans. This reduces the bank's income, which has an effect on the CAR. According to the findings of Williams (2011) and Yuanjuan (2012), as well as Fathiyah Andini and Irni Yunita (2015), NPL has a negative and significant effect on CAR. The following hypothesis is based on the preceding description:

$\mathrm{H}_{1} \quad$ Non-Performing Loan (NPL) has a negative and significant effect on the Minimum Capital Adequacy Requirement (CAR).

2) The Effect of Return on Asset on Minimum Capital Adequacy Requirement (CAR)

Yuliani et al. (2015) stated that the higher the Return on Assets (ROA), the higher the level of profit earned by the bank and the better the bank's position in terms of asset use. This is aligned with Sakinah's statement (2013) saying that if a bank experiences a loss, its capital drops in value, and vice versa, if the bank earns a profit, its capital increases. Previous research (Irdawati et al., 2018) shows that ROA has a substantial beneficial impact on CAR, thus the hypothesis in this study is:

$\mathrm{H}_{2}$ Return on Assets (ROA) has a positive and significant effect on the Minimum Capital Adequacy Requirement (CAR).

3) The Effect of Return on Equity on Minimum Capital Adequacy Requirement (CAR)

The return on equity (ROE) is the amount of profit after taxes on equity. The bank's rising ROE implies that its net profit after tax is rising as well, implying that its own capital will rise, and the CAR is projected to increase (Sorongan, 2020). Previous study by Bahtiar et al. (2019) and Paudel \& Khanal (2015) demonstrated that ROE has a positive and significant influence on CAR. The following hypothesis is based on the preceding description:

$\mathrm{H}_{3} \quad$ Return on Equity (ROE) has a positive and significant effect on the Minimum Capital Adequacy Requirement (CAR).

4) The Effect of Loan to Deposit Ratio on Minimum Capital Adequacy Requirement (CAR)

LDR is the ratio of loans made to third parties (excluding loans to other banks) to third-party funds, which include demand deposits, savings accounts, and time deposits (excluding inter-bank funds). If the bank's third-party funds 
are not routed as credit (idle money), the bank will miss the chance to earn interest on the loans granted. Given that credit is the bank's primary source of revenue (Taswan, 2015). This will have an effect on the bank's income, causing the accumulated profit for capital to fall and, as a result, the CAR to fall. Previous studies [1] demonstrated that LDR has a positive and significant effect on CAR. Therefore, the hypothesis is:

$\mathrm{H}_{4} \quad$ Loan to Deposit Ratio (LDR) has a positive and significant effect on the Minimum Capital Adequacy Requirement (CAR).

\section{RESULTS AND DISCUSSION}

\section{A. Figures and Tables Model Estimation}

There are 3 model estimates in panel data regression including Common Effect Model (CEM), Fixed Effect Model (FEM), and Random Effect Model (REM):

a. Common Effect Model (CEM)

It is a simple panel data model since only time series and cross-section are combined.

b. Fixed Effect Model (FEM)

It is a model with a different intercept in each cross section, but the slope does not vary over time (Gujarati, 2012).

c. Random Effect Model (REM)

Random Effect Model (REM) is panel data estimated by the model, where the residual variable is considered to correlate between time and subject. This model is used to overcome the lack of fixed effects by using dummy variables (Widarjono, 2009).

To estimate the model, the usual least squares (OLS) method is used by CEM and FEM in panel data regression used, while the generalized least squares (GLS) method is used by REM.

\section{B. Model Selection}

1) The best model between CEM and FEM is selected in Chow Test

FEM is chosen if the value of Cross-Section Chi-Square is less than 0.05, while CEM is chosen if the value of CrossSection Chi-Square is more than 0.05. If CEM is selected in this situation, the Lagrange Multiplier Test is performed. However, if FEM is selected, it continues to the Hausman Test.

\begin{tabular}{|c|c|c|c|}
\hline \multicolumn{4}{|c|}{$\begin{array}{c}\text { TABLE I: CHOW TEST (FIXED EFFECT N } \\
\text { Redundant Fixed Effects Tests }\end{array}$} \\
\hline \multicolumn{4}{|c|}{$\begin{array}{c}\text { Equation: FEM_BK1 } \\
\end{array}$} \\
\hline \multicolumn{4}{|c|}{ Test cross-section fixed effects } \\
\hline Effects Test & Statistic & d.f. & Prob. \\
\hline Cross-section F & $2,497,791$ & -1.6 & 1.146528 \\
\hline $\begin{array}{l}\text { Cross-section Chi- } \\
\text { square }\end{array}$ & $4,176,561$ & 1 & 0.284722 \\
\hline
\end{tabular}

It is shown in Table I that the value of Cross-section ChiSquare $0.0410<0.05$, therefore, Hausman test is conducted.

2) Selection of the best model between FEM and REM in the Hausman Test

if the value of Cross-Section Chi-Square $<0.05$, FEM is selected. While REM is chosen if the value of Cross-Section Chi-Square $>0.05$. In this case, if FEM is chosen, it is obvious that FEM is the best model. Nevertheless, if REM is chosen, the Lagrange Multiplier test is going to be conducted. This BUKU I consists of two companies (cross-section) with 5 total coefficients namely 1 dependent variable coefficient and 4 independent variable coefficients so that the REM model cannot be carried out (Random effects estimation requires a number of cross-sections > number of coefs for between estimator for estimate of RE innovation variance).

\section{Model Interpretation}

The selected model for BUKU I according to Chow test and Hausman test is Fixed Effect Model with the equation model:

$$
\begin{aligned}
Y= & -17.8380-0.21815 \times X 1+0.2986 \times X 2- \\
& 0.05136 \times X 3+0.37334 \times X 4+e
\end{aligned}
$$

\begin{tabular}{|c|c|c|c|c|}
\hline Variable & Coefficient & Std. Error & $\mathrm{t}$-Statistic & Prob. \\
\hline $\mathrm{C}$ & $-1,783,807$ & $7,973,494$ & $-2,237,171$ & 0.4625 \\
\hline $\mathrm{X} 1$ & -0.218152 & $1,510,480$ & -0.144426 & 6.179861111 \\
\hline $\mathrm{X} 2$ & 0.269863 & 0.829165 & 0.325464 & 5.249305556 \\
\hline $\mathrm{X} 3$ & -0.051363 & 0.107309 & -0.478643 & 4.507638889 \\
\hline $\mathrm{X} 4$ & 0.373343 & 0.051619 & $7,232,596$ & 0.0004 \\
\hline \multicolumn{5}{|c|}{ Effects Specification } \\
\hline \multicolumn{5}{|c|}{ Cross-section fixed (dummy variables) } \\
\hline R-squared & 0.910476 & \multicolumn{2}{|c|}{ Mean dependent var } & $1,684,583$ \\
\hline $\begin{array}{l}\text { Adjusted R- } \\
\text { squared }\end{array}$ & 0.835872 & \multicolumn{2}{|c|}{ S.D. dependent var } & $7,468,684$ \\
\hline $\begin{array}{l}\text { S.E. of } \\
\text { regression }\end{array}$ & $3,025,765$ & \multicolumn{2}{|c|}{ Akaike info criterion } & $5,359,058$ \\
\hline $\begin{array}{l}\text { Sum squared } \\
\text { resid }\end{array}$ & $5,493,152$ & \multicolumn{2}{|c|}{ Schwarz criterion } & $5,601,511$ \\
\hline $\begin{array}{l}\text { Log } \\
\text { likelihood }\end{array}$ & $-2,615,435$ & \multicolumn{2}{|c|}{ Hannan-Quinn criter. } & $5,269,293$ \\
\hline F-statistic & $1,220,419$ & \multirow{2}{*}{\multicolumn{2}{|c|}{ Durbin-Watson stat }} & $2,109,382$ \\
\hline $\begin{array}{l}\text { Prob(F- } \\
\text { statistic) }\end{array}$ & 0.004243 & & & \\
\hline
\end{tabular}

TABLE II: FIXED EFFECT MODEL

Source: Output Eviews 9, (processed data).

\section{1) Regression Results}

The findings of multiple regression based on the regression model are explained as follows:

1. The multiple linear regression equation owns the constant value of -17.838 . If the independent variable is considered to be constant, the dependent variable, CAR, will drop by 17.838 percent, according to the value of the constant.

2. NPL variable coefficient $=-0.218$, implying that a $1 \%$ rise in NPL reduces CAR by 0.218 percent.

3. ROA variable coefficient $=0.269$, meaning that a $1 \%$ increase in ROA would result in a 0.269 percent rise in CAR.

4. ROE variable coefficient $=-0.051$, which means that every $1 \%$ rise in ROE reduces CAR by $0.051 \%$.

5. LDR variable coefficient $=0.373$ meaning that each LDR increase by $1 \%$ will increase the CAR by $0.373 \%$.

\section{2) Coefficient of Determination}

It is used to understand the independent variable's significant influence on the dependent variable. The coefficient of determination is determined by the value of Rsquared. The R-square value of $0.91(91 \%)$ in Table II indicates that $\mathrm{X} 1, \mathrm{X} 2, \mathrm{X} 3$, and $\mathrm{X} 4$ by $83 \%$ can explain the $\mathrm{Y}$ variable, while other variables outside the model can explain the remaining 9 percent $(100 \%-91 \%=9 \%)$. 


\section{3) Individual Partial Significance Test (T-test)}

It is used in testing whether there is an effect between the index of the independent variable and the dependent variable. If the probability of significance $>0.05$, then the rules used have no significant effect or accept $\mathrm{H} 0$ and reject $\mathrm{H} 1$. Then, if the probability of significance $<0.05$, there is a significant effect or reject $\mathrm{H} 0$ and accept $\mathrm{H} 1$.

1) The prob. value of $\mathrm{X} 1$ is $0.88>0.05$. Therefore, $\mathrm{H} 0$ is accepted and $\beta$ is (-). This indicates that NPL has a negative and insignificant influence on CAR, thus that hypothesis (H1) stating "NPL has a negative and significant effect on CAR," is rejected.

2) The prob. value of $\mathrm{X} 2$ is $0.75>0.05$. Therefore $\mathrm{H} 0$ is accepted and $\beta$ is $(+)$. This indicates that ROA has a positive and insignificant effect on CAR, therefore that hypothesis (H2) stating "ROA has a positive and significant effect on CAR" is rejected.

3 ) The prob. value of $\mathrm{X} 3$ is $0.64>0.05$. Hence $\mathrm{H} 0$ is accepted and $\beta$ is (-). This indicates that CAR is negatively and insignificantly affected by ROE, therefore the hypothesis (H3) stating "ROE has a positive and significant effect on the Minimum Capital Adequacy Requirement (CAR) is rejected.

4) The prob. value of $\mathrm{X} 4$ is $0.00>0.05$. Hence $\mathrm{H} 0$ is rejected and $\beta$ is $(+)$. This indicates that LDR gives a positive and significant effect on CAR, thus, hypothesis (H4) stating LDR has a positive and significant effect on the Minimum Capital Adequacy Requirement (CAR) is accepted.

\section{Result Interpretation}

\section{1) The Effect of NPL on CAR}

According to the test results on processed data using software reviews 9.0, the NPL had a negative influence on KPPM that was not significant. This is in line with the study "Impact of Non-Performing Loans (NPL), Liquidity, and Profitability on Capital Adequacy Ratio" (Dewa Ayu Anjani \& Ni Ketut Purnawati, 2012) which shows that NPL has a negative and minor influence on CAR. If the NPL rises, the bank must, in theory, increase its reserves for earning assets. As a result, revenue, profits, and capital are all affected. The reduction in the capital led to a reduction in CAR.

However, if the CAR is larger than risk-weighted assets

due to increased core and supplementary capital, the CAR is unaffected by NPL. The impact of POJK No. 12/POJK.03/2020 regarding the Consolidation of Commercial Banks on the increase in core capital in BUKU I banks is also the impact of POJK No. 12/POJK.03/2020 regarding the Consolidation of Commercial Banks, which requires banks to meet a minimum capital requirement of $\mathrm{Rp}$ 3 trillion in 2022, which takes effect in December 2020. As a result, in Fig. 1, The performance of CAR in 2015-2020 may be shown for BUKU I. The performance of CAR continues to improve.

\section{2) The Effect of ROA on CAR}

According to the results of the tests, ROA has a positive and non-significant effect on CAR. This can happen as a result of high other operating expenses (commissions / provisions / fees and administration, losses from reduced value of financial assets (impairment), labour costs, and other costs) that are not matched by increased financing (credit distribution), resulting in a profit from revenue that is less than expected. The interest earned is put towards covering other operating costs and completing the financing request. It is supported by Yuliani et al. (2015).

\section{3) The Effect of ROE on CAR}

The findings of the tests demonstrate that ROE has a negative and insignificant effect on CAR. This is owing to the fact that the rise in profit after tax (net income) achieved by banks through business development was less than the increase in income and operating expenses. This contradicts the findings of Bokhari (2013), Wong (2005), and Romdhane (2012), which show that ROE has a negative and significant impact on CAR.

\section{4) The Effect of LDR on CAR}

The findings of this study show that LDR has a good and significant impact on CAR. CAR is positively and considerably influenced by LDR, which is in line with the research of Shitawati (2006) and Abusharba (2013). This is due to the fact that bank loans can be higher than the distribution of Third-Party Funds (DPK), resulting in a bigger interest income than the payment of interest costs. As a result, banks will be able to enhance net profit, which will have a positive impact on capital growth, bigger interest income than the payment of interest costs. As a result, banks will be able to enhance net profit, which will have a positive impact on capital growth.

\section{CONCLUSION AND SugGeSTION}

\section{A. Conclusion}

The purpose of this study is to see if Non-Performing Loan (NPL), Return on Asset (ROA), Return on Equity (ROE), and Loan to Deposit Ratio (LDR) have an impact on the Minimum Capital Adequacy Requirement (CAR) on BUKU I. The data for this study was gathered from each bank's financial reports from 2015 to 2019 . The purposive sampling method is used to choose the banking sample. The following are the findings based on the panel data regression estimation and hypothesis testing results:

a. CAR banks on BUKU I have increased in 2018-2020.

b. The influence on CAR of $91 \%$ can be explained by NPL, ROA, ROE, and LDR, while other variables outside the model explain the rest $(100 \%-91 \%=9 \%)$.

c. NPL has a negative and insignificant effect on CAR in BUKU I banks for the 2015-2020 period.

d. ROA has a positive and insignificant effect on CAR in BUKU I banks for the 2015-2020 period.

e. CAR is negatively and insignificantly affected by ROE in BUKU I banks for the 2015-2020 period.

f. LDR has a positive and significant impact on CAR in BUKU I banks for the 2015-2020 period.

\section{B. Suggestion}

The following suggestions are proposed from the results of the study:

a. For Banking

1) Excessive NPL reduces banks' ability to channel credit, which, of course, increases the risk of bad loans. The 5C and $7 \mathrm{P}$ principles should be implemented more effectively in bank management. 
2) Banks should continue to raise the value of ROA and ROE because increased profits demonstrate that the company's assets and total equity have been handled properly.

3) Banks must maintain the LDR Ratio in accordance with Bank Indonesia rules, ensuring that it remains within the recommended range of 80 percent to 110 percent. The reason for this is because a bank's LDR that is too low or too high will have a detrimental influence on the bank's viability. It is expected that the bank will always maintain the amount of credit given so that its ratio to the amount of public funds and own capital used does not turn out to be quite liquid, or even less liquid and illiquid, and that the bank would have reserves to meet depositor obligations if cash held is not possible.

b. For Investors

1) It is suggested that investors need to understand the signs given by companies through movement of the Bank's financial performance such as Return on Asset (ROA), Return on Equity (ROE), Non-Performing Loan (NPL), along with Loan to Deposit Ratio (LDR) as indicators t see the health of the bank from the adequacy of capital owned.

2) CAR performance in BUKU I 2018-2020 continues to increase, as a result it becomes a good opportunity for investors to invest their money.

c. For Further Research

1) It is suggested that in future study, other factors be utilised to test against the Minimum Capital Adequacy Requirement (CAR).

2) Pay close attention to the most recent rules published by the authorities, particularly those related to Financial Ratios.

\section{REFERENCES}

Andini, F., \& Yunita, (2015). Analisis Pengaruh Return on Asset (ROA), Return on Equity (ROE), Non-Performing Loan (NPL), Dan Loan to Deposit Ratio (LDR) Terhadap Capital Adequacy Ratio (CAR) Pada Perusahaan Perbankan Dindonesia. E-Proceeding of Management, 2 (2), 1384-1391.

Dewa Ayu Anjani, \& Ni Ketut Purnawati. (2012). Pengaruh Non-Performing Loan (NPL), Likuiditas Dan Rentabilitas Terhadap Rasio Kecukupan Moda, Fakultas Ekonomi dan Bisnis Universitas Udayana.

Irdawati, Ansir, \& Sinarwati. (2018). Pengaruh Faktor Fundamental Mikro Terhadap Capital Adequacy Ratio (The Effect of Micro Fundamental Factors on Capital Adequacy Ratio), Jurnal Manajemen, Bisnis Dan Organisasi, e-ISSN: 2502-4175, 2(3), 12-26.

Kasmir (2014). Dasar-Dasar Perbankan, 12th ed, PT. RajaGrafindo Persada, Jakarta.

Prasetya Adi Pratama. (2013)., Pengaruh NIM, NPL, ROA, LDR dan BOPO Terhadap Capital Adequacy Ratio (CAR), Journal of Chemical information and Modeling, 53(9), 1689-1699.

Purnama Sari, A., Kusumawardhani, A., and Manajemen, J. (2016). Analisis Pengaruh NPL, BOPO, LDR, Dan Nopfe Terhadap CAR (Studi Empiris: Bank Pembangunan Daerah Sendonesia Periode 2012-2015, Diponegoro Journal of Management, 5(4), 1-8.

Riyadi, S. (2006). Banking Assets and Liability Management (Ed. 3). Jakarta: Lembaga Penerbit Fakultas Ekonomi Universitas Indonesia.

Williams \& Harley Tega (2011). Determinants of Capital Adequacy in The Banking Sub-Sector of the Nigeria Economy: Efficacy of Camels. (A Model Specification with Co-Integration Analysis). International Journal of Academic Research in Business and Social Sciences, 1 (3), pp: 233-248.

Yuanjuan, Li and Xiao Shishun (2012), Effectiveness of China's Commercial Banks' Capital Adequacy Ratio. Interdisciplinary Journal of Contemporary Research in Business, 4 (1), pp: 58-68.
Yuliani, K. P., Werastuti, D. N. S., and Edy, S. (2015) Pengaruh Loan to Deposit Ratio (LDR), Non-Performing Loan (NPL), Return on Asset (ROA) dan Opersional terhadap Pendapatan Operasional (BOPO) terhadap Capital Adequacy Ratio (CAR) (Studi Pada Bank Umum Swasta Nasional (BUSN) Devisa), E-Journal Ak S1 Universitas Pendidikan Ganesha, 3(1), 1-11.

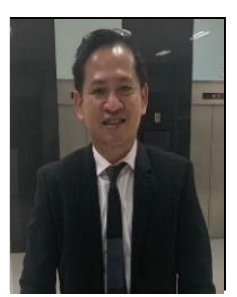

Rano Rahadian was born on Otober 04, 1977 in West Java. Indonesia. Bachelor Degree from University of Ahmad Yani (West Java, Indonesia) majoring in Chemical Science in 2001. Master of Management in Finance Management from University of Mercu Buana (Jakarta, Indonesia) in 2021.

Before he become Manager of Credit Risk in Bank Banten Indonesia, he has experience in Banking Industry from Operational staff in CIMB Niaga Bank, Bank Mega Syariah Bank, and Bank Mandiri also Internal Auditor in Bank Banten.

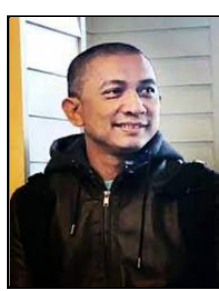

Associate Professor Dudi Permana, Ph. D was born on March 18th, 1977 in West Sumatera Indonesia. Bachelor Degree have graduated from Andalas University majoring in Mechanical Engineering in 2001, Master of Management in Strategic Management graduated from Andalas University (West Sumatera-Indonesia) in 2006 and $\mathrm{PhD}$ in Strategic Management graduate from University of Science Malaysia.

Before active in academic field, he has experienced in Mining Industry as Deputy Service Department Head (PT. United Tractors Tbk), in Kideco Mining (East-Kalimantan, Indonesia). He also awarded Certified Professional Marketer from Asian Marketing Federation (AMF) and Certified as Assessor in Human Resource Management from National Agency for Professional Certification (BNSP-Indonesia). His research interest in Strategic Management, Banking Industry Issues, Islamic Marketing, Digital Marketing and Sustainability Issues. 